\title{
Erogenous Zones: Described in Old Sanskrit Literature
}

\author{
R. Nambisan"1, K. P. Skandhan' ${ }^{2}$ \\ ${ }^{1}$ Senior Medical Officer Government Ayurveda Hospital, Ponnani, India \\ ${ }^{2}$ Department of Physiology, Sree Narayana Institute of Medical Sciences, Chalakka, India \\ Email: kpskandhan@gmail.com
}

Received 29 November 2013; revised 29 December 2013; accepted 6 Janaury 2014

Copyright (C) 2014 by authors and Scientific Research Publishing Inc.

This work is licensed under the Creative Commons Attribution International License (CC BY). http://creativecommons.org/licenses/by/4.0/

\section{(c) (i) Open Access}

\section{Abstract \\ Our knowledge on erogenous points in both male and female is limited. We present here the vast knowledge on the same availability which existed in India during the 13th century.}

\section{Keywords}

\author{
Erogenous Zones, Moon Influence, Lunar Month, Synodic Month, Sexual Excitement, \\ Sexual Pleasure
}

\section{Introduction}

Sex secured deserving attention and was discussed in depth largely in private circle, during early years in India. The best example for their knowledge is "Kamasutra” by Vatsyayanamuni [1], the foremost and eminent writing on the subject in Sanskrit. Unknown to the modern world is yet another elaborate study on erogenous zones present in men and women influenced by moon.

We present here an abstract of the said erogenous zones working under the influence of moon. This is based on four prominent publications of the first half of last century. Originaly this was written anytime before the 13th century.

\section{Discussion}

An accepted fact is that human body in health and diseases is influenced by celestial bodies like sun and moon. There are several examples. Sleep is the best we know. Asthma patients experience severity of the condition during late night and early morning [2]. Accumulated data with psychiatric practitioners prove a lunar rhythm in emotional behaviors, more homicides and aggravated assaults around the time of full moon [3].

Our current knowledge on erogenous areas is restricted to lips, mouth, tongue, breast, certain portions of ge- 
nitalia and sometimes the area surrounding anus, or in general any area where nerve ending is excitable [4]. No specific areas or points other than these are known otherwise. However in old Sanskrit literature detailed and elaborated observations on this which is unknown to modern world. It described two types of erogenous zones [5]. For convenience, we name them as permanent and temporary. The first group is called as permanent, because these zones are excitable on any time of the day. They are totally four-cheeks, lips, breast and genitalia. The second group, temporary, deserve great attention and is detailed below:

There are thirty areas tipped for this function; equally and identically distributed on left and right sides of the body. These fifteen areas on a half are given in Table 1 . They are labeled as temporary, because, each area is capable of causing sexual excitation only on a particular day in a synodic or lunar month (=29.5306 days ${ }^{*}$ ) (Some widely used calenders in the world are based on lunar position. A popular Hindu calendar in Northern India is an example). Figure 1 represents the erogenous zones in men and women. The right half of Figure 1 gives the descriptive picture of erogenous zones present on the left side of a woman, also the extreme right of Figure 1, the days of a lunar calendar are represented. Connecting the erogenous zones to lunar calendar we can see on left side scalp as the excitable area on the first day of the lunar calendar, (the next day after "no moon

Table 1. Erogenous zones locations and types of stimuli described by different authors.

\begin{tabular}{|c|c|c|c|c|}
\hline \multirow[b]{2}{*}{ Erogenous Zones } & \multicolumn{4}{|c|}{ Authors } \\
\hline & Dixit [5] & Jyoteeswara-Charya [12] & Iyengar [9] & Kokkakka [8] \\
\hline Toes & Pressing with toes & ------- & Pressing with toes & Pressing with toes \\
\hline Foot & Pressing with feet & Caressing & Striking with foot & Pressing with feet \\
\hline Ankle & Pressing with ankle & Kissng & Pressing with ankle & Pressing with ankle \\
\hline Knee & Pressing with knees & ---- & Pressing with knees & Pressing with knee \\
\hline Public Region & $\begin{array}{l}\text { "Matangaleela" } \\
\text { (See text) }\end{array}$ & “Matangaleela” & “Matangaleela” & “Matangaleela” \\
\hline Naval & ----- & Slow patting & Slow patting & Slap with open hand \\
\hline Chest & Patting & Stroke with fist & Stroke with fist & Stroke \\
\hline Breast & Pressing & Patting/Fondling & Fondling & $\begin{array}{l}\text { Squeezing with pressure } \\
\text { (fondling) }\end{array}$ \\
\hline Arm pit & ----- & Scraping with nail & Scraping with nail & Scraping with nail \\
\hline Neck & ----- & ------ & ----- & Scraping with nail \\
\hline Cheek & Biting with teeth & $\begin{array}{l}\text { Biting with teeth/Scraping } \\
\text { with nail }\end{array}$ & Vigorous kissing & Kissing vigorously \\
\hline Lips & Squeezing hard with Lips & ------ & $\begin{array}{l}\text { Kissing using } \\
\text { lips with teeth }\end{array}$ & Squeezing with teeth and lips \\
\hline Eyelid & $\begin{array}{l}\text { Pressing smoothly } \\
\text { while kissing }\end{array}$ & ------ & $\begin{array}{l}\text { Pressing smoothly } \\
\text { while kissing }\end{array}$ & \\
\hline Eye & ----- & ------ & ------ & Kissing \\
\hline Forehead & ------- & ------ & Kissing/Patting & Kissing \\
\hline Scalp & ----- & ----- & ------ & Pulling the hairs \\
\hline Head & Low patting & Pulling hairs & Pulling hairs & \\
\hline Thigh & ----- & Pressing with thigh & ----- & \\
\hline Waist & ----- & Nail Scraping & ----- & \\
\hline Parting of hair & ----- & Nail Scraping & ----- & \\
\hline
\end{tabular}

"The new Encyleopedia Britanica, $15^{\text {th }}$ edition, volume 12, 1980, p. 415. 


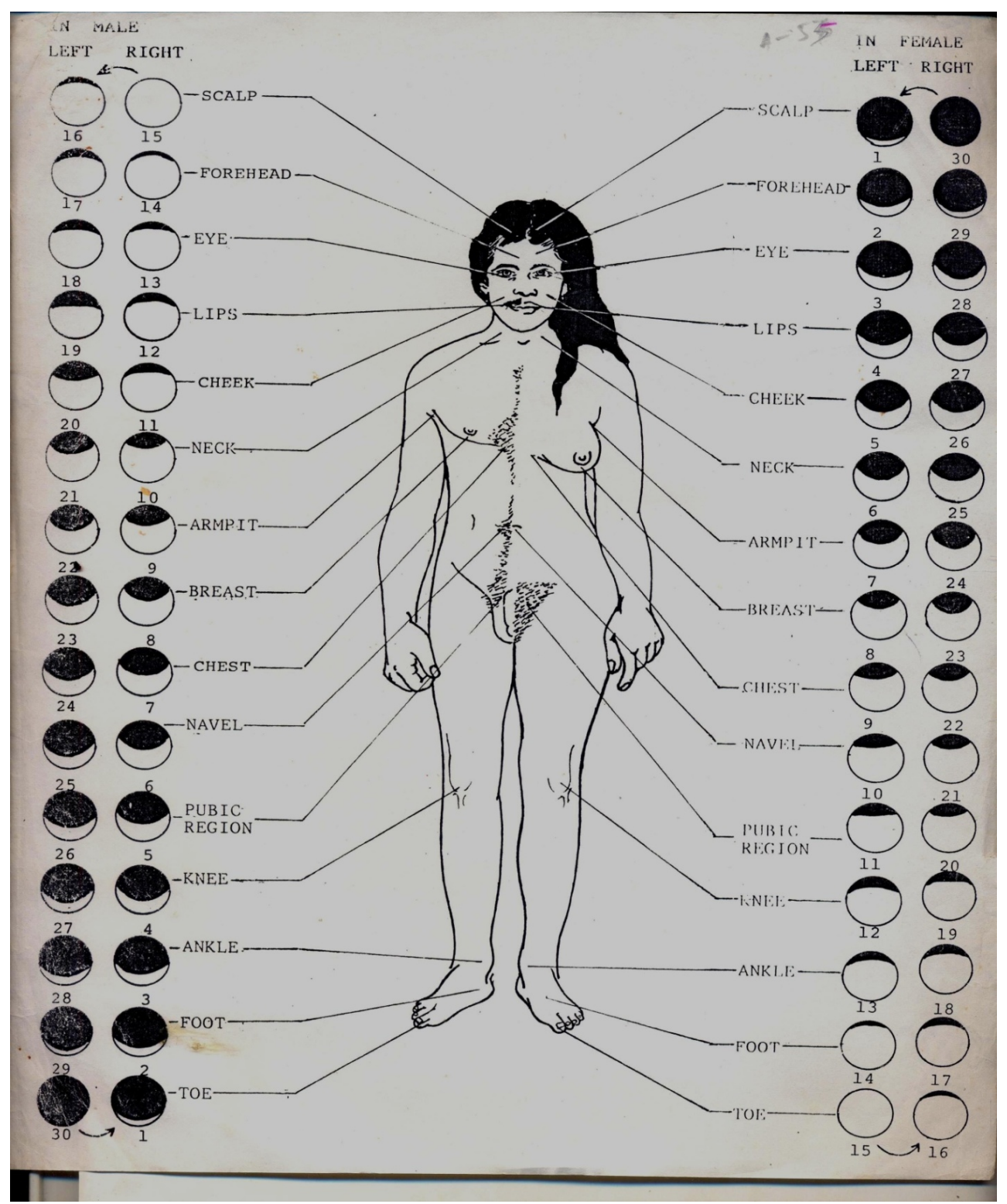

Figure 1. Showing erogenous zones in male and female. Each zone could be stimulated on a single lunar day.

day”.) On the second in the lunar calendar, the excitable area is at a lower level, forehead. Day by day the erogenous zones descend as shown in Figure 1 and reach "toe" on "full moon day". From sixteenth day onwards the similar areas on the opposite side (right) are excitable in a reversible order; on sixteenth day toe, and on thirtieth day-(“no moon day”)-scalp.

The relationship between lunar position and erogenous area in male is in reverse order in comparison to female. Linking the lunar calendar given on extreme left of Figure 1 with the right side of a man clearly shows that in the first half of lunar calendar, right side is for stimulating and on the first lunar day "toe" is his erogenous zone. From there, the areas designated are in ascending order; on second day-foot; on third day-ankle... And on fifteenth day ("full moon day")-scalp. After the completion on the right side a shift on erogenous zones take place to the left side; sixteenth day-scalp, on seventeenth day-forehead... and reaching "toe" on thirtieth day ("no moon day").

The strength of stimulus is an important criterion for exciting any receptor including that of an erogenous zone. Touch and pressure in multiple leads to pain which inhibit the sexual excitement. Stimulus measured is in terms of voltage, pulses and time. In a natural phenomenon like sexual act, stimuli were suitable selected and 
incorporated by pioneers. Each area was designated for a stimulus with a particular strength. The strength was labeled by different workers as kissing, licking, patting, striking, slapping, squeezing, pressing, scrapping... (Table 1) is elephant's sexual play. Translation to this may lead us to, light touch, patting, fondling... In general, the question of whether the receptors respond to different positions of moon or sun is not known clearly well today. However, clinicians agree that the broncho-constriction occurring in asthma patients due to parasympathetic tone was prominent in dark hours [2]. Similarly, in lunatics the "full moon day" might be leading to increased neurotransmitter substances for their exacerbated behavior [3]. It may be the same with receptors discussed which respond better to a stimulus on a particular lunar day than others.

The veracity of each zone is equivalent to the level of our knowledge about "G" spot which was first described by Grafenberg [6]. Gynecologists were embarrassed by missing this spot from their routine examination for all earlier years [7]. Today "G" spot is accepted as the most potent area in vagina for sexual stimulation. Kinsey and his group of workers had stated that skin anywhere, is capable of making sexual arousal, sometimes may even lead to orgasm [4]. Considering the existing facts, the erogenous zones described in old Sanskrit literature sounds true and a detailed study on this shall confirm the same.

\section{Conclusion}

The art presented here must have been in practice in India in palaces and fortresses surely not among common people [8]. A king, Sri Devaraja Maharaja (1659-1704) of eminent Mysore Kingdom, himself presented the art in print for private circulation [9]. For the amusement of a prince Khan, son of Ahmed of Lodhi Kingdom, it was rewritten in the 16th century [10]. The art got lost at last for reasons better known to historians. Albiruni, a scholar from Central Asia who visited India in the early 17th century wrote about Indians, "they are selfish by nature, niggardly in communicating which they know, and they take the greatest possible care to withhold it from men on another caste among their own people, still much more, of course, from any foreigner” [11].

\section{Acknowledgements}

The authors acknowledge Dr. Godatwar Pawankumar for preparing Figure 1 of this manuscript.

\section{References}

[1] (1929) Vatsyayanamuni’s Kamasutra. Vidyavilas Press, Banaras.

[2] Ganong, W.F. (1989) Review of Medical Physiology. 14th Edition, Princeton Hall International Inc., Connectievet.

[3] Storebel, C.F. (1985) Biological Rhythms in Psychiatry. In: Kalpan, H.I. and Sadock, B.J., Eds., Comprehensive Text Book in Psychiatry IV, Williams and Wilkins.

[4] Kinsey, A.C., Pomeroy, W.B., Martino, E. and Gebhard, P.H. (1953) Sexual Behavior in the Human Female. WB Saunders Company, Philadelphia.

[5] Dixit, M.P. (1942) Kelikuthuhalam. Khagesa Press, Banaras.

[6] Grafenberg, E. (1950) The Role of the Urethra in Female Orgasm. International Journal of Sexology, 3, 145-149.

[7] Weisenberg, M. (1984) Physiology of Female Sexual Functions. Clinical Obstetrics and Gynecology, 27, 697-705. http://dx.doi.org/10.1097/00003081-198409000-00017

[8] Kokokka, M. (1922) Ratirahasyam (The Secret of Sexual Pleasure). Permanent Company, Banaras.

[9] Iyengar, R.P. (1923) Ratiratnapradipika. Royal Press, Mysore.

[10] Schmidt, R. (1927) Kallyanamallasanangaranga. Punjab Sanskrit Pustakalay, Banaras.

[11] Dev, A. (1990) The Story of Civilization. National Council of Educational Research and Training, New Delhi.

[12] Jyoteeswaracharya, S.K. (1923) Panchasayaka. Vidyavilas Press, Banaras. 